\title{
The Environmental Awareness Profile of Elementary School Pre-Services Teacher
}

\author{
Siti Patonah ${ }^{1}$, Sentot Budi Rahardjo ${ }^{1}$ Cari $^{1}$, Sajidan $^{1}$ \\ ${ }^{1}$ Doctorate Program Universitas Sebelas Maret, JI. Ir. Sutami 36A Kentingan Surakarta \\ Indonesia
}

\begin{abstract}
Damage to the environment around us is increasing. The role of education is very strategic to make improvements, especially early education. Prospective elementary teachers as an educator at a low level should be able to carry out this role effectively. The purpose of this study was to level of knowledge of pre-service elementary school to the environment and care. The research method used is survey method cross sectional survey, using environmental awareness questionnaire. The sample was taken randomly for each class that is $2^{\text {nd }}$ semester, $4^{\text {th }}$ semester and $6^{\text {th }}$ semester. 164 students of pre-service teacher elementary school as a sample in research consisted of 36 male and 134 female, University of PGRI Semarang, Central Java Indonesia academic year 2016 / 2017. Data were analyzed descriptively to obtain the expected information. Based on the data obtained, it is known that the environmental awareness of pre-service teacher elementary school of the lowest position is the environmental awareness of animals and plants, while the environmental awareness of the highest energy use. Awareness for prospective elementary school pre-services teacher on the environment is still low.
\end{abstract}

Keywords: environmental awareness; elementary school; pre-services teacher

\section{INTRODUCTION}

Earth is the only planet that can be inhabited by humans and other living things. Damage to one part of the earth causes damage to other parts[1]. Damage globally begins with environmental damage that surrounds each individual. Various environmental damage is mostly caused by human activities that at all times meet the needs of his life[2]. The discrepancy between the number of human needs and the availability of natural resources causes environmental damage. Therefore, human beings as thinkers have a major role in maintaining a balanced environment. Among the process of habituating the environment is through education[3];[4].

The lowest formal education level is primary school. The primary school grid becomes the determinant of useful habits in the next level, even throughout life. The introduction of maintaining the environment is very important taught from an early age [5]. The role of teachers is crucial to the success of maintaining an environment that leads to environmental care. The preparation of elementary school pre-services teacher to be able to familiarize their students care about the environment becomes 
something that needs to be continuously pursued. Education plays an important role to increase environmental awareness of students [6];[7], Educational atmosphere helps students familiarize themselves with building environmental awareness[8]. University as a "small city"[9];[10], where all cultures, habits, knowledge, and complex activities are combined are a suitable means to prepare people with high awareness of the environment. Since the first semester students have been introduced and practiced to practice environmental awareness activities. Environmental awareness practices emerged from students' knowledge. Knowledge then moves his motor to do real activity, not just stop as knowledge [11], Giving embrace to awareness to always care about the environment.

There are at least 3 concepts about environmental concerns, namely: emotions, attitudes, and sustainable practices[12];[2]. All three are packaged in a program known as environmental education. Environmental education is concerned with the development of community awareness, values and attitudes, enabling them to engage effectively in sustainable development[13]. However, some studies indicate a lack of knowledge and low environmental concerns in prospective elementary school preservices teachers[14];[15]. It is important to know the extent of environmental awareness of prospective elementary teachers, so that it can be used as a foothold to provide the right treatment for optimizing the role of pre-services teacher to prepare themselves as change agents in the face of environmental problems.

\section{METHOD}

\section{Participant}

This research used survey method, cross sectional survey to explore the level of awareness of prospective elementary school teachers. Through the random sampling, each force is represented by one class for force 2 and 4, while force 6 is taken as many as 2 classes. As many as 243 students consist of 193 female students and 50 male students spread in 3 different semester: semester 2, 4, and 6 are given environmental awareness questionnaires. Students used as samples are PGSD students of PGRI University of Semarang, Central Java, Indonesia.

\section{Measures}

All participants answered a questionnaire about environmental concerns consisting of 60 items within 30 minutes. An environmental awareness questionnaire used using a questioner adapted from University Technology Malaysia with the permission of the owner. Questionnaires use Likert scale 1 to 5 , where 5 for "strongly agree" statements, 4 for "agree", 3 "for neutral statements", 2 for "disagree" statements, and 1 for "strongly disagree" statements. The results obtained are then analyzed descriptively to describe the profile and level of environmental awareness. 


\section{Data Analysis}

Data analysis is being done using a descriptive analysis to get the level of environmental awareness of prospective elementary school pre-services teachers.

\section{RESULTS AND FINDING}

\section{The Respondent Characteristics}

Of the total 164 students, 2 students in the 4th semester leaving 2 items unanswered; 2 students in the 2nd semester who chose the answer scales more than one for one statement, while for the 6th semester, there were 2 people leaving one item not filled and 1 person choosing the answer scale more than one for one statement. From the data obtained, table 1, showing the demographic characteristics of the respondents, is described below:

- Gender: About two-thirds (79\%) of the respondents were female, and the rest were male.

- Age: 62\% were aged between 20-22 years, representing the highest rate of participation, followed by $37 \%$ for $17-19$ years. For $23-25$ had the lowest participant, at $1 \%$.

- Grade: The highest grade partcipant is $6^{\text {th }}(48 \%)$, followed by $2^{\text {nd }}$ grade $(28 \%)$ and $4^{\text {th }}(24 \%)$.

- Transport use to campus: most of the respondents using motorcycle to go to campus $(68 \%)$, followed by walk $(23 \%)$. No student using bicycle to go to campus.

TABLE I. RESPONDENT'S DEMOGRAPHIC FACTORS

\begin{tabular}{|llll|}
\hline Variable & Scale & $\begin{array}{l}\text { Frequenc } \\
\text { y }\end{array}$ & Total (\%) \\
\hline Gender & Female & 130 & 79 \\
& Male & 34 & 21 \\
Gge Group (year) & $17-19$ & 63 & 37 \\
& $20-22$ & 103 & 62 \\
Grade & $23-25$ & 1 & 1 \\
Transport use to campus & 2 & 46 & 28 \\
& 4 & 39 & 24 \\
& 6 & 79 & 48 \\
& Walk & 39 & 23 \\
& Car & 1 & 0,5 \\
& Motorcycle & 115 & 68 \\
& Bicycle & 0 & 0 \\
& Bus & 2 & 2 \\
& Mix mode & 11 & 6,5 \\
\hline
\end{tabular}




\section{Environmental Awareness Levels}

Based on the questioner used there are 4 indicators of environmental awareness used, namely: care about water use, care about energy use, care about the presence of waste, and care for animals and plants. The distribution of the questionnaire according to the indicator is shown in table 2. For the score of each indicator shown in graph 1.

TABLE II. SPREAD OF THE QUESTIONNAIRE BASED ON ENVIRONMENTAL AWARENESS INDICATORS

\begin{tabular}{|lllc|}
\hline Indicator & Number of Item & Total & (\%) \\
\hline Environmental awareness of water & $1,5,19,24,25,29,30$ & 7 & 11 \\
use & & & \\
Environmental awareness of energy & $7,10,12,18,20,21,23,27$, & 18 & 30 \\
use & $32,33,38,39,40,41,45,4$ & & \\
& $7,51,56$ & & \\
Environmental awareness of waste & $2,3,4,8,9,11,13,14,15,1$ & 31 & 51 \\
& $6,17,22,26,28,31,34,35$, & & \\
& $42,43,44,48,49,50,52,5$ & & \\
& $3,54,55,57,58,59,60$ & & \multirow{2}{*}{0,06} \\
Environmental awareness of animal & $6,36,37,46$ & 4 & \\
and plant & & & \\
\hline
\end{tabular}

The Level of Environmental Awareness

豆 2 丞 4 6 6

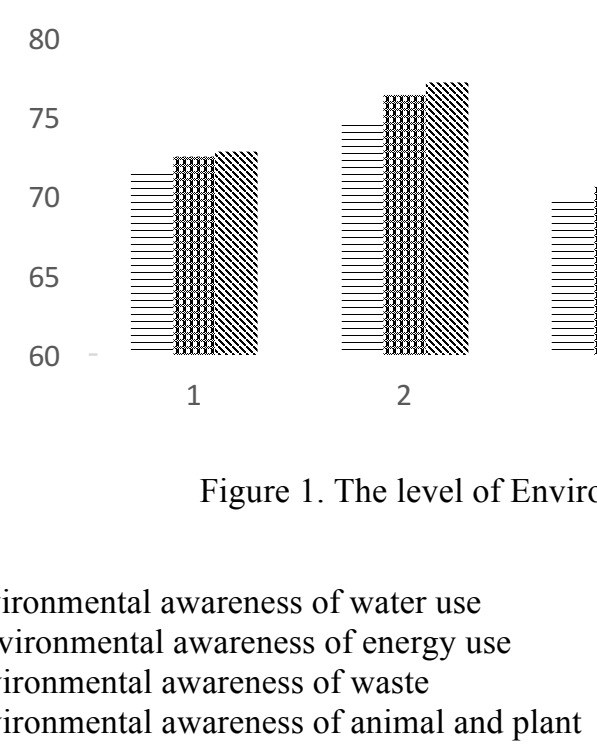

For the level of environmental awareness of each indicator at each level shown in table 3. 
TABLE III. LEVEL OF ENVIRONMENTAL AWARENESS BY GRADE

\begin{tabular}{|lccl|}
\hline \multicolumn{1}{|c}{ Indicators of Environmental Awareness } & \multicolumn{3}{c|}{ Grade } \\
& $2^{\text {nd }}$ & $4^{\text {th }}$ & $6^{\text {th }}$ \\
\hline Environmental awareness of water use & 71,62 & 72,53 & 72,83 \\
Environmental awareness of energy use & 74,81 & 76,41 & 77,19 \\
Environmental awareness of waste & 69,94 & 70,62 & 70,4 \\
Evironmental awareness of animal and plant & 67,89 & 68,46 & 67,77 \\
\hline
\end{tabular}

\section{DISCUSSION}

Teachers are key to the success of education, including environmental education. Education is the first line of defense to make changes, spread awareness and affect one's behavior [6];[16]. To cultivate high environmental awareness and take concrete action needs to be well prepared for prospective elementary school teachers. In this study, the data of the number of prospective primary school teachers is dominated by female $(79 \%)$. High expectations of this potential that female students have a high concern for the environment compared with male students[12];[17];[18]. Environmental awareness owned by a person have not been fully realized in real activity[19];[20]. This is indicated by the dominance of prospective elementary school pre-services teacher using motorcycles rather than walking, bicycle, or public transportation with various variations of vehicles, such as public transportation, bus, pedicab and so forth.

For environmental awareness of elementary school pre-services teacher, from semester 2 to semester 6 have a high concern on energy use, this is quite different from what has been studied by Fawzi[21], In which as much as $70 \%$ of the average respondent cares about water use. The next sequence is to care about the use of water, care about the presence of waste and care for animals and plants. Subsequent research needs to examine the relationship of environmental awareness with the ability to think creatively, the possibility of linkage between the two.

\section{CONCLUSION}

The level of environmental awareness of prospective elementary school teachers at PGRI University Semarang is at a moderate level for environmental awareness of energy use, followed by environmental awareness of water use and the presence of waste. Environmental awareness of animals and plants is still low.

\section{ACKNOWLEDGMENT}

We would like to thank for grant PNBP UNS Year 2017 with document number $623 / \mathrm{UN} 27.21 / \mathrm{PP} / 2017$ that has provided support and stimulation to publish this article. 


\section{REFERENCES}

[1] P. C. Stern, O. R. Young, and D. Druckman, Global environmental change: Understanding the human dimension. 1992.

[2] N. S. Mei, C. W. Wai, and R. Ahamad, "Environmental Awareness and Behaviour Index for Malaysia," Procedia - Soc. Behav. Sci., vol. 222, no. 7, pp. 668-675, 2016.

[3] N. Koruoglu, I. Ugulu, and N. Yorek, "Investigation of High School Students' Environmental Attitudes in Terms of Some Demographic Variables," no. October, pp. $1608-1623,2015$.

[4] S. S. Alfuhaigi, "School Environment and Creativity Development: a Review of Literature," J. Educ. Instr. Stud. World, vol. 5, no. 2, pp. 33-38, 2015.

[5] M. S. Aini and P. Laily, "Preparedness of Malaysian pre-school educators for environmental education," Pertanika J. Soc. Sci. Humanit., vol. 18, no. 2, pp. 271-283, 2010.

[6] A. M. Freije, T. Hussain, and E. A. Salman, "Global warming awareness among the University of Bahrain science students," J. Assoc. Arab Univ. Basic Appl. Sci., pp. 9-16, 2015.

[7] X. Yuan, M. She, Z. Li, Y. Zhang, and X. Wu, "Mutual awareness: Enhanced by interface design and improving team performance in incident diagnosis under computerized working environment," Int. J. Ind. Ergon., 2016.

[8] A. Toom, J. Pietarinen, T. Soini, and K. Pyhältö, "How does the learning environment in teacher education cultivate first year student teachers' sense of professional agency in the professional community?," Teach. Teach. Educ., vol. 63, pp. 126-136, 2017.

[9] H. M. Alshuwaikhat and I. Abubakar, "An integrated approach to achieving campus sustainability: assessment of the current campus environmental management practices," $J$. Clean. Prod., vol. 16, no. 16, pp. 1777-1785, 2008.

[10] A. Sarsour and A. Ayoub, "Full Length Research Paper A Preliminary Assessment for the Environmental Awareness of the Universities 'Students in Gaza strip- Palestine," vol. 3, no. 3, pp. 85-93, 2015.

[11] N. A. Rahman, "Knowledge, internal, and environmental factors on environmental care behaviour among aboriginal students in Malaysia," Int. J. Environ. Sci. Educ., vol. 11, no. 12, pp. 5349-5366, 2016.

[12] H. Altaher, "Management of Environmental Quality: An International Journal Article information :," Manag. Environ. Qual. An Int. J., 2013.

[13] J. Palmer, Environmental education in the 21st Century. 1998.

[14] D. Saribas, G. Teksoz, and H. Ertepinar, "The relationship between environmental literacy and self-efficacy beliefs toward environmental education," vol. 116, pp. 3664-3668, 2014.

[15] A. Yumuşak, S. A. Sargın, F. Baltacı, and R. R. Kelani, "Science and Mathematics Teacher Candidates' Environmental Knowledge, Awareness, Behavior and Attitudes," Int. J. Environ. Sci. Educ., vol. 11, no. 6, pp. 1337-1346, 2016.

[16] P. Demir and S. S. Avgin, "Global Warming and Measures to be Taken: Pre-Service Science Teachers' Views," vol. 7, no. 27, pp. 128-135, 2016.

[17] S. Arslan, "The Influence of Environment Education on Critical Thinking and Environmental Attitude," Procedia - Soc. Behav. Sci., vol. 55, no. October 2012, pp. $902-$ 909, 2012.

[18] M. Tesfai, U. S. Nagothu, J. Šimek, and P. Fučík, "Perceptions of secondary school students' towards environmental services: A case study from Czechia," Int. J. Environ. Sci. Educ., vol. 11, no. 12, pp. 5533-5553, 2016.

[19] C. a. Klöckner, "A comprehensive model of the psychology of environmental behaviour - A meta-analysis," Glob. Environ. Chang. vol. 23, no. 5, pp. 1028-1038, 2013.

[20] B. G. Bergman, "Environmental Education Research Assessing impacts of locally designed environmental education projects on students' environmental attitudes, awareness, and intention to act," no. July, 2015.

[21] R. Fawzi, M. Ameen, and M. Mourshed, "Urban environmental challenges in developing countries d A stakeholder perspective," vol. 64, 2017. 